\title{
A Lower Palaeozoic 'onychophoran' reinterpreted as a pelmatozoan (stalked echinoderm) column
}

\author{
Freek Rhebergen 1 and Stephen K. Donovan ${ }^{2}$ \\ 1 Slenerbrink 178, NL-7812 HJ Emmen, The Netherlands \\ ${ }^{2}$ Department of Geology, University of the West Indies, Mona, Kingston 7, Jamaica
}

Date Received August 18, 1993

Date Accepted October 7, 1993

\begin{abstract}
Onychophorans are rare fossils, but are currently the subject of renewed research activity. However, not all 'onychophorans' have been correctly identified. The specimen described herein is preserved as a natural mould in an Upper Ordovician cobble from a Quaternary glacial deposit. The 'legs' are actually elongate tubercles, arranged in irregular circlets and showing calcite cleavage; the annulations of the body are irregularly spaced. The specimen is reinterpreted as a pelmatozoan, probably crinoid, pluricolumnal.
\end{abstract}

\begin{abstract}
Les onychophores sont des fossiles rares, mais font présentement l'objet d'une activité de recherche renouvelée. Toutefois, ce ne sont pas tous les "onychophores» qui ont été correctement identifiés. Le spécimen décrit ici est préservé comme un moulage naturel dans un caillou Ordovicien supérieur provenant d'un dépôt glaciaire quaternaire. Les «pattes» sont en fait des tubercules allongés, disposés en cercles irréguliers et montrant des clivages de calcite; les annulations du corps sont irrégulièrement espacées. Le spécimen est réinterprété comme un pelmatozoaire, probablement un crinoïde à plusieurs tiges.
\end{abstract}

[Traduit par la rédaction]

\section{INTRODUCTION}

The specimen documented herein was originally described by the senior author as a possible onychophoran (Rhebergen, 1990). Subsequent discussion with Dr. A.B. Smith (Natural History Museum, London) led to the suggestion that it should more correctly be interpreted as a pelmatozoan, probably crinoid, pluricolumnal. This reinterpretation is supported by the present authors and is the subject of this note. This communication is considered timely, in the light of recent interest in Lower Palaeozoic onychophorans (see, for example, Ramsköld, 1992; Gould, 1993; Anon, 1993). Terminology of the crinoid column used herein follows Moore et al. (1968), Webster (1974) and Ubaghs (1978).

\section{LOCALITY AND STRATIGRAPHY}

The specimen is a natural mould in a silicified, glacial erratic cobble of Baltic origin. It was collected from one of the sand-pits in the Wilsumer Berge, a complex of ice-pushed ridges in westernmost northwest Germany, county of Bentheim. The locality lies in the northeast part of this complex $\left(52^{\circ} 33^{\prime} \mathrm{N}\right.$, $6^{\circ} 53^{\prime} \mathrm{E}$; Fig. 1).

The specimens from this deposit of Ordovician age occur in cobbles and pebbles which originated from eroded Caradoc and Ashgill marine sequences in several areas of the Baltic, most probably from the region north of Gotland and west of Estonia. Between the Miocene (or earlier) and the middle Pleistocene these clasts were transported southwards by both glacial and fluvial action. During the early Pleistocene (Menapian; see Harland et al., 1990, fig. 3.17), fluvial transport of arenaceous sediments led to the deposition of the Enschede Formation
(Zagwijn, 1974), including the specimen described herein. During the Saalian the upper part of this unit was reworked by fluviglacial action and partly mixed with local Pliocene (and perhaps also with older Pleistocene [Eburonian]) sediments. Finally, the Saalian glacier pushed up this sedimentary sequence, including the unreworked lower part of the Enschede Formation, to form the present ridge system.

The Baltic material in the Wilsumer Berge consists of numerous Ordovician sponges and tabulate corals, and silicified, more or less chertified limestone cobbles, with some Lower Cambrian, partly quartzitic, sandstones. So far no examples of Silurian silicification have been recognized. The only erratics of Silurian limestones in this region are found in certain Saalian till deposits. The process of silicification of the Ordovician material probably took place in the original rock during the Palaeozoic, associated with the deposition of overlying bentonite deposits.

Five principal types of Ordovician silicification can be distinguished (Table 1). However, some cobbles cannot easily be classified within this system. For example, the specimen described herein is one of only two similar specimens out of a collection of about 12,000 examined by the senior author. Its unusual palaeontological characteristics are discussed below.

\section{Systematic Palaeontology \\ Class Crinoidea? Miller, 1821 Incerti ordinis \\ Pelmatozoan pluricolumnal indet.} (Figs. 2, 3)

Material: A single specimen, Archiv für Geschiebe, Geological Institute, University of Hamburg (UH) AGH-G 124-1. 


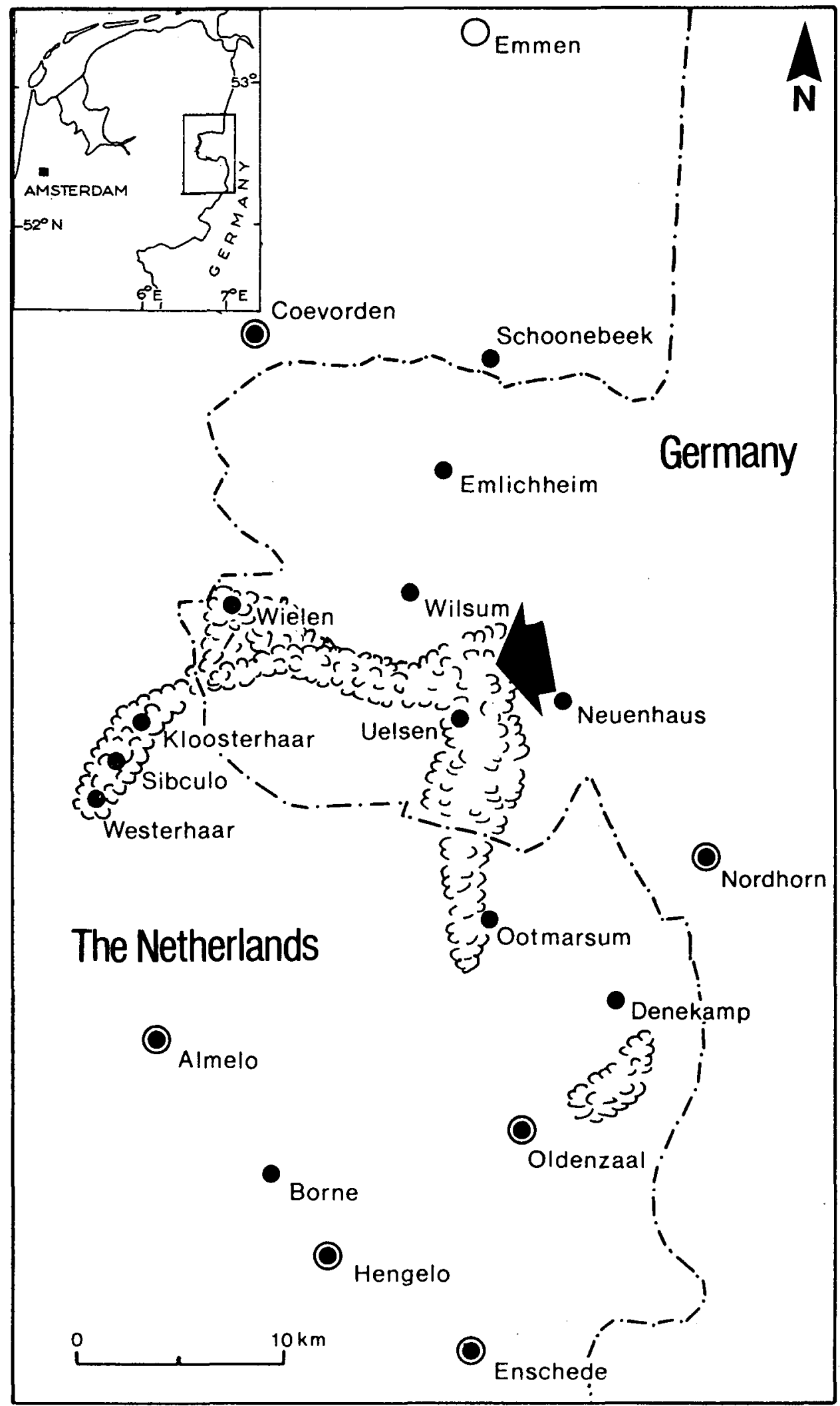

Fig. 1. Map showing the position of the fossil locality in the Wilsumer Berge (arrowed), close to the border between the Netherlands and Germany. The inset map shows the position of the main map in northwest Europe.

Occurrence: See above. One of the accompanying fossils in this cobble is a cast of a librigena (= free cheek) of Asaphus sp. or Neoasaphus sp., which suggests a probable Caradoc age.
Description: Articular facet and lumen not preserved. Articulation unknown. Column heteromorphic, possibly N212. Nodals highest, internodals low. Latera planar, but nodals bear numer- 
Table 1. Principal types of silicified Middle and Upper Ordovician limestones found in the Wilsumer Berge

$\begin{array}{lll}\text { Type Age Lithology: Occurrence: Fauna } & \end{array}$

$1 \quad$ Caradoc (Estonian stages $\mathrm{C}_{2 \mathrm{c}}-\mathrm{D}_{2}$ )

2 Middle Ordovician

3 Caradoc to Ashgill (Estonian stages $\mathrm{C}_{3}, \mathrm{D}$ and $\mathrm{F}_{10}$ )

4

Ashgill (Estonian stages $\mathrm{F}_{1 \mathrm{c}}-\mathrm{F}_{2}$ )

5
Yellow-grey, brick-like, porous, usually highly weathered, ('Backsteinkalk'): \pm 60\%: algae (Mastopora concava Eichwald, Coelosphaeridium cyclocrinophilum Roemer, Apidium krausei (Kiesow) Stolley), trilobites (Chasmops marginata Schmidt), brachiopods (Platystrophia sp.); less common bryozoans, crinoid ossicles, cephalopods, hyolithids; rare conulariids, cystoids and Bothriocidaris sp. cf. B. pahleni Schmidt.

Yellow-brown, strongly leached out, including grains of and fossils altered to chalcedony: $\pm 8 \%$ : few fossils, but including algae (Apidium? sp.), cystoids (Echinosphaerites? sp.) and rare Bothriocidaris sp.

Grey-blue, chert-like silicifications: $\pm 2 \%^{*}$ : algae (Cyclocrinites spp., mostly C. porosus Stolley), brachiopods and gastropods.

Flint-like chert ('Öjlemyrflint'**): $\pm 16 \%$ : rich fauna of microfossils (Schallreuter, 1984), with ostracodes, bryozoans, trilobites (Erratencrinurus (Celtencrinurus) kiaeri Owen, Decoroproteus sp.), brachiopods and algae (Apidium rotundum Høeg and indeterminate species).

Very fine-grained, silt-like silicifications, possibly Öjlemyr-limestone cobbles: $\pm 9 \%$ : similar fauna to the crusts of cobbles in 4 .

Percentages are based on the examination of about 3,600 cobbles by the senior author. Key: ${ }^{*}=$ this is the most common type of clast in the island of Sylt (north Germany), but is the rarest in the Wilsumer Berge; the original Baltic location is unknown, but is considered to be in south Finland, or even the upper Gulf of Bothnia or Lappland (Krueger, 1990); ${ }^{* *}=$ Öjlemyrflint only occurs in Gotland, Sylt and Wilsumer Berge, cobbles often seeming to have broken from larger nodules; the original Baltic location is uncertain, but is thought to have been west of Finland or in south Finland (Schallreuter, 1984).

ous tubercles (estimated 20 to 30 per nodal) elongated in long axis of column and with a marked median ridge (Figs. 2, 3). Tubercles may extend onto or over adjacent columnals, so adjacent circlets of tubercles may overlap. At least one nodal shows an undulose articulation with the adjacent internodal (Fig. 3.2), with nodal highest at the tubercles and narrowing between them. Tuberculation greatest towards one end of specimen (bottom in Fig. 2).

Measurements: Pluricolumnal about $70 \mathrm{~mm}$ long and about $15 \mathrm{~mm}$ wide. The width of a complete column would be greater, as this specimen only represents about one third of the circumference.

Discussion: This specimen, although incomplete, shows a number of features that demonstrate an echinoderm, rather than onychophoran, affinity. In the English summary of Rhebergen's original description (1990, p. 131), it was stated that the "...fossil consists of a concave subcylindrical, straight mould, showing a pattern of papillas in longitudinal and transversal rows. Be- tween them there are a number of regularly repeated annuli." The 'papillae' lack onychophoran features such as terminal claws (Barnes, 1980, pp. 804-810), are elongated with a median ridge, and at least one was broken off before burial, revealing a calcite cleavage (Fig. 3.1). They are better interpreted as tubercles, as seen on the latera of certain Palaeozoic crinoid columns (see, for example, Donovan, 1989, pl. 11, fig. 6). The annuli (Fig. 2) separate the fossil into high segments with tubercles, separated by series of lower, non-tuberculated, segments. Segments are of varying thicknesses, but show a regular arrangement. These are considered to be the sutures between individual pelmatozoan columnals.

However, although undoubtedly a pelmatozoan, a more precise classification of this specimen is difficult. Large, cylindrical columns with such a sculpture are unknown among blastozoans, so, almost by default, it is part of a crinoid. The function of the very numerous tubercles is not clear, but possibilities include anchorage of a distal, recumbent stem, protection (considered to be most likely), or perhaps (but improbably) deflection of water currents towards the crown (compare with 


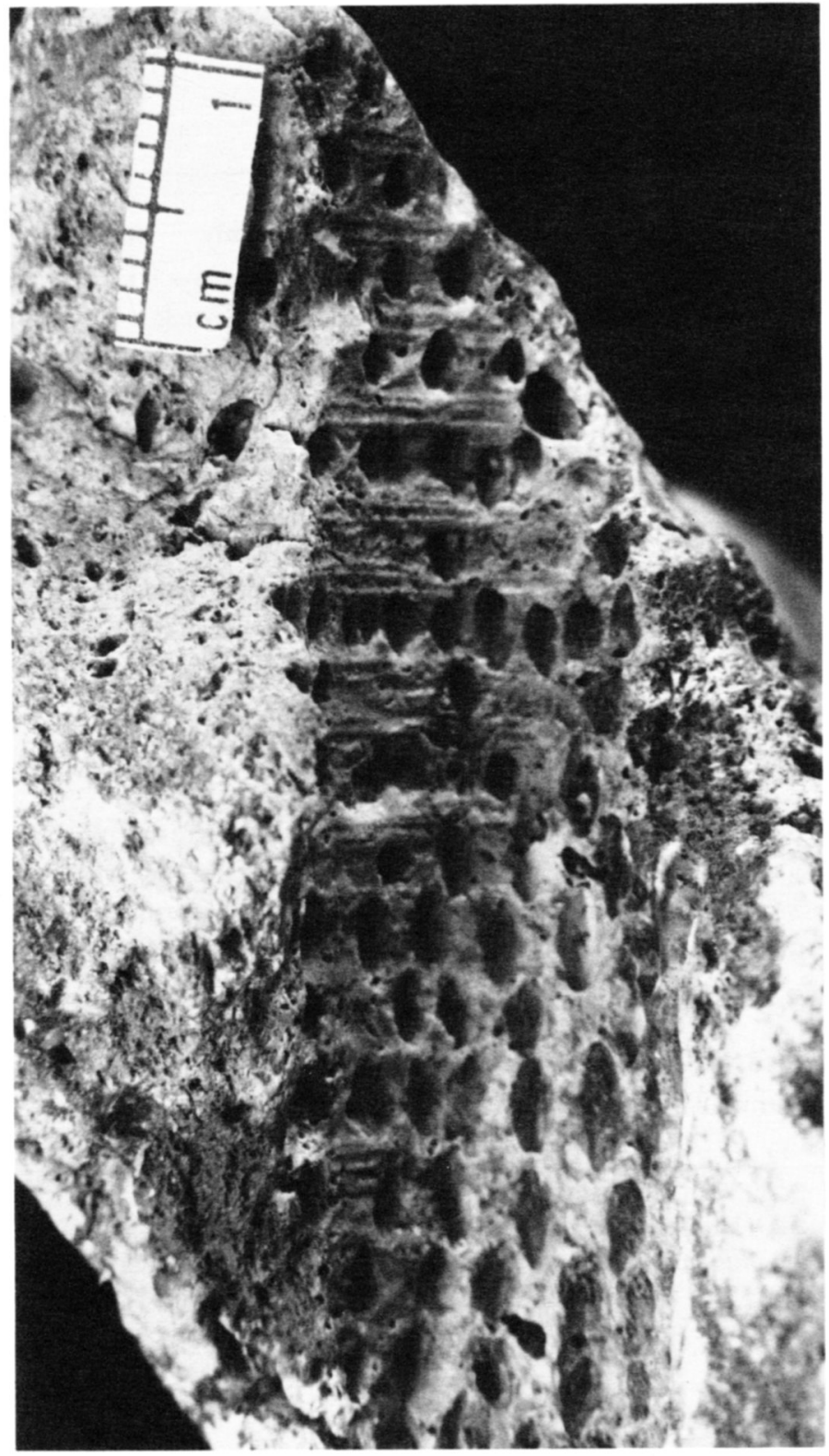

Fig. 2. Pelmatozoan pluricolumnal indet., UH AGH-G 124-1 (collected by F.R.), Wilsumer Berge, northwest Germany. Natural mould.

Riddle, 1989). The first possibility is suggested by the large diameter of the specimen, which may indicate that it is from the more distal part of a column. Nodal columnals which swell around the tubercles, so that the articulation with the adjacent internodals is undulose, were probably inflexible and the major flexibility of the column would have been between the low internodals.

\section{ACKNowledgements}

We thank Mr. Cornelis J. Veltkamp, Department of Environmental and Evolutionary Biology, University of Liverpool, for taking the scanning electron micrographs reproduced in Figure 3 .

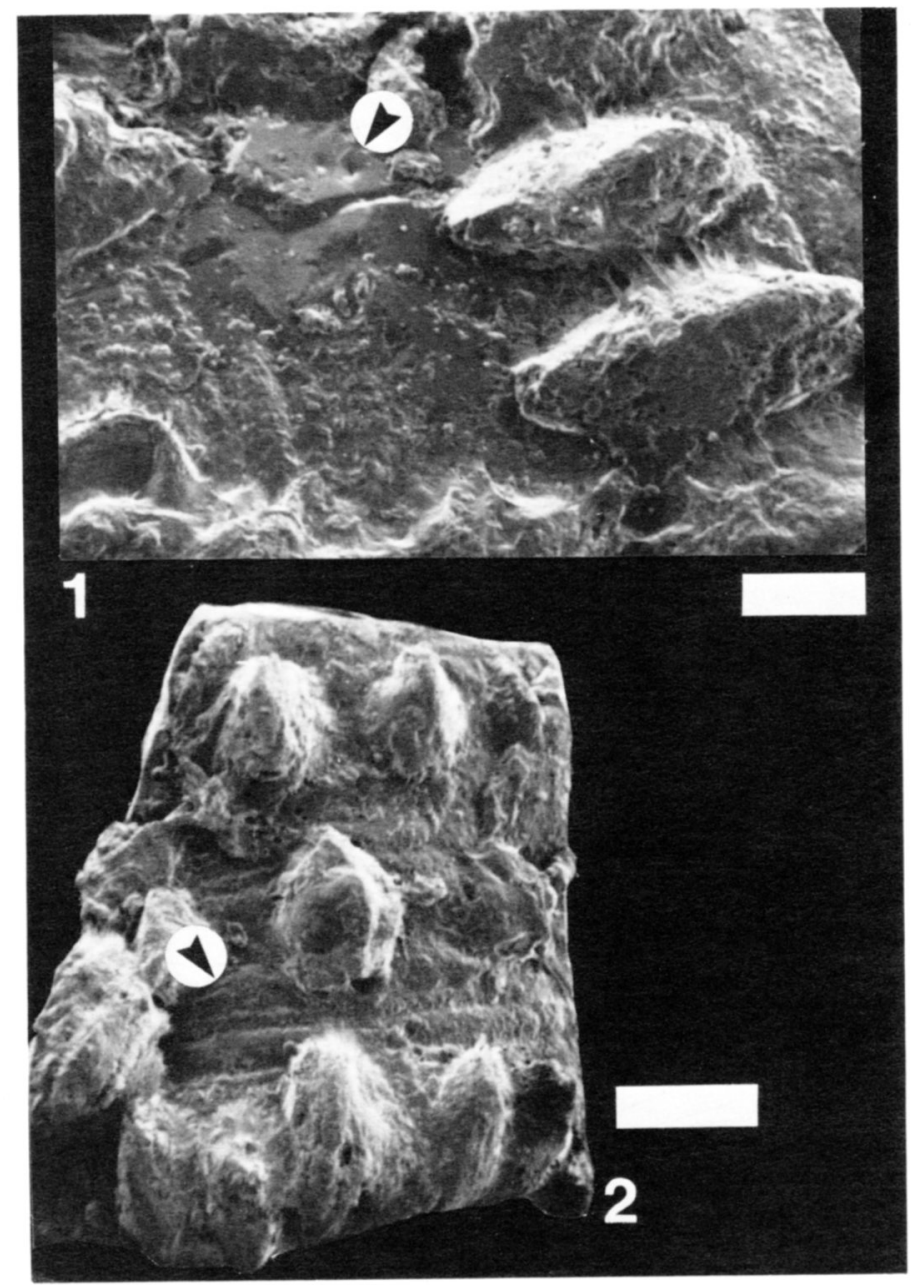

Fig. 3. Scanning clectron micrographs of a latex cast taken from $\mathrm{UH}$ AGH-G 124-1. (1) Detail of latus showing elongate tubercles. Arrow indicates a region wherc a tubercle has apparently been broken off, leaving three prominent calcite cleavages. Scale bar represents $1 \mathrm{~mm}$. (2) Part of the pluricolumnal showing undulose sutures (arrowed) between tuberculated and non-tuberculated columnals. Scale bar represents $2 \mathrm{~mm}$.

ANon. 1993. Boomtime for onychophoran studies. American Paleontologist, 1, p. 3.

Barnes, R.D. 1980. Invertebrate Zoology. Fourth edition. Saunders College, Philadelphia, 1089 p.

Donovan, S.K. 1989. Pelmatozoan columnals from the Ordovician of the British Isles, part 2. Palaeontographical Society Monographs, 142 (for 1988), no. 580, pp. 69-114.

Gould, S.J. 1993. The reversal of Hallucigenia. In Eight little piggies. By S.J. Gould. W.W. Norton, New York, pp. 342-352.

Harland, W.B., Armstrong, R.L., Cox, A.V., Crajg, L.E., Smith, A.G., and SMITH, D.G. 1990. A geologic time scale 1989. Cambridge University Press, Cambridge, $263 \mathrm{p}$.

Krueger, H.H. 1990. Fossilinhalt der nordischen Geröllgemeinschaft aus der Lausitz (Miozän) und deren Vergleich mit Sylt. In Fossilien von Sylt 3. Edited by $U$. von Hacht. Verlag und Verlagsbuchhandlung Inge-Maria von Hacht, Hamburg, pp. 179-211.

Miller, J.S. 1821. A natural history of the Crinoidea or lily-shaped animals, with observations on the genera Asteria, Euryale, Comamla, and Marsupites. Bryan and Company, Bristol, $150 \mathrm{p}$. 
MoORE, R.C., JefFords, R.M., and Miller, T.H. 1968. Morphological features of crinoid columns. The University of Kansas Paleontological Contributions, Echinodermata, Article 8, pp. 1-30.

RAMsKóld, L. 1992. Homologies in Cambrian Onychophora. Lethaia, 25 , pp. 443-460.

RHEBergen, F. 1990. Een raadselachtig fossiel: ?Onychophora? Grondboor en Hamer, 44, pp. 130-131.

RIDDLE, S.W. 1989. Functional morphology and paleoecological implications of the platycrinitid column (Echinodermata, Crinoidea). Journal of Paleontology, 63, pp. 889-897.

SChallReuter, R. 1984. Geschiebe-Ostrakoden I. Neues Jahrbuch für Geologie und Paläontologie, Abhandlungen, 169, pp. 140.
Ubaghs, G. 1978. Skeletal morphology of fossil crinoids. In Treatise on Invertebrate Paleontology, Part T, Echinodermata 2(1). Edited by R.C. Moore and C. Teichert. Geological Society of America and University of Kansas Press, Boulder and Lawrence, pp. T58-T216.

WeBster, G.D. 1974. Crinoid pluricolumnal noditaxis patterns. Journal of Paleontology, 48, pp. 1283-1288.

ZaGwis, W.H. 1974. Palaeogeographic evolution of the Netherlands during the Quaternary. Geologie en Mijnbouw, 53, pp. 369-385. 